\title{
The evolution of product placement: Consumer awareness and ethical considerations
}

\author{
Leigh Ann Hornick \\ West Virginia University
}

Follow this and additional works at: https://researchrepository.wvu.edu/etd

\section{Recommended Citation}

Hornick, Leigh Ann, "The evolution of product placement: Consumer awareness and ethical considerations" (2006). Graduate Theses, Dissertations, and Problem Reports. 3232.

https://researchrepository.wvu.edu/etd/3232

This Thesis is protected by copyright and/or related rights. It has been brought to you by the The Research Repository @ WVU with permission from the rights-holder(s). You are free to use this Thesis in any way that is permitted by the copyright and related rights legislation that applies to your use. For other uses you must obtain permission from the rights-holder(s) directly, unless additional rights are indicated by a Creative Commons license in the record and/ or on the work itself. This Thesis has been accepted for inclusion in WVU Graduate Theses, Dissertations, and Problem Reports collection by an authorized administrator of The Research Repository @ WVU. For more information, please contact researchrepository@mail.wvu.edu. 
The Evolution of Product Placement:

Consumer Awareness and Ethical Considerations

\title{
Leigh Ann Hornick
}

\author{
Thesis submitted to the \\ Perley Isaac Reed School of Journalism \\ at West Virginia University \\ in partial fulfillment of the requirements \\ for the degree of
}

Master of Science in Journalism

Dana C. Coester, Chair

George J. Esper, Ph.D.

Ivan Pinnell, Ph.D.

Mary L. Schultz

Journalism Department
Morgantown, West Virginia
2006

Keywords: Product Placement, Brand Placement, Persuasion, Manipulation 


\section{ABSTRACT \\ The Evolution of Product Placement and its Impact On Consumers Today}

\section{Leigh Ann Hornick}

Found today in virtually every type of media, the practice of product placement has been around since the First World War. The concept of this form of advertising stems from the idea that studio executives are constantly seeking out cost effective ways to produce movies and marketers' are supporting ways to get their products seen. Moreover, advertisements are becoming a thing of the past with new technological devices that allow viewers to skip commercials. It was found throughout this study that although consumers are aware of the practice and deem it ethical, they still vastly believe it can be a deceptive form of advertising. 
TABLE OF CONTENTS

THE EVOLUTION OF PRODUCT PLACEMENT: CONSUMER AWARENESS AND ETHICAL CONSIDERATIONS...........................................................

ABSTRACT ...........................................................................

TABLE OF CONTENTS....................................................................

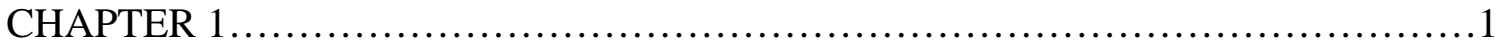

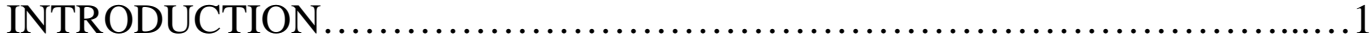

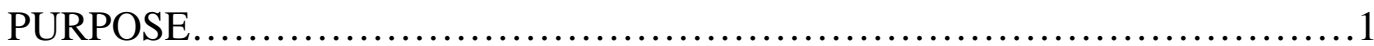

RESEARCH QUESTIONS............................................

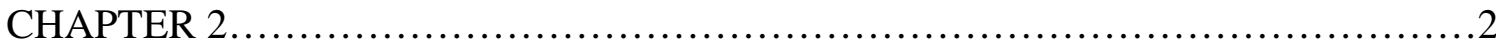

REVIEW OF LITERATURE .................................................

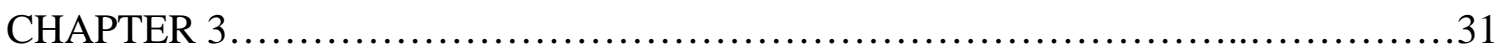

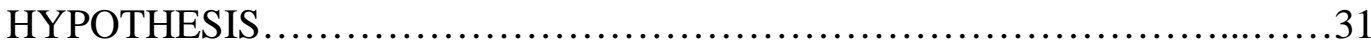

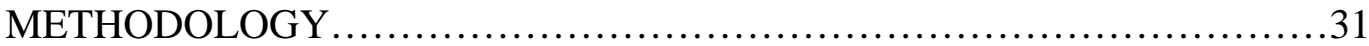

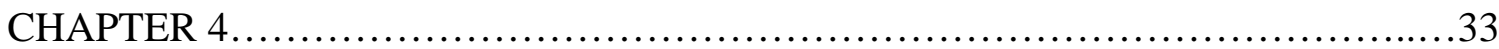

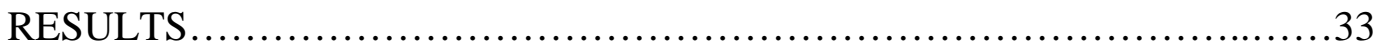

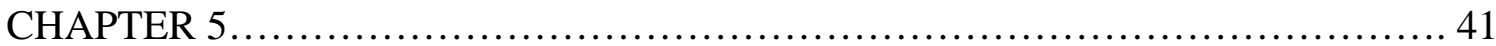

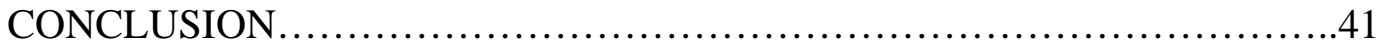

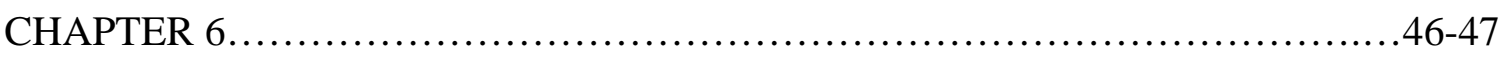

SELECTED BIBLIOGRAPHY ........................................

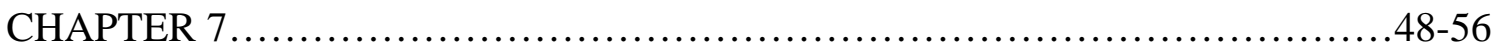

APPENDIX A: CONTRACT SHEET ..................................48-49

APPENDIX B: STUDENT SURVEY ................................. $50-55$

APPENDIX C: ERMA CODE OF ETHICS.................................56 


\section{TABLES}

Table

Page

1.1 Sex of Respondents........................................................ 34

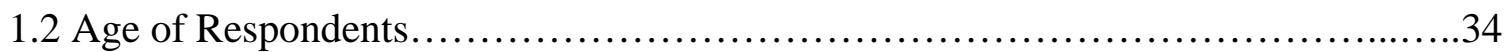

1.3 Viewing Habits of Respondents........................................... 34

2.1 Genre of Television Program Most Often Watched...............................35

2.2 If Most Watched Program Contains Product Placement...........................35

2.3 News and Educational Programming ...........................................

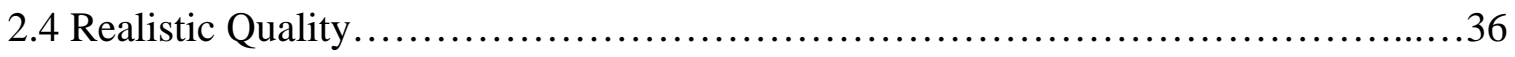

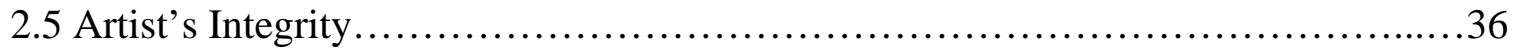

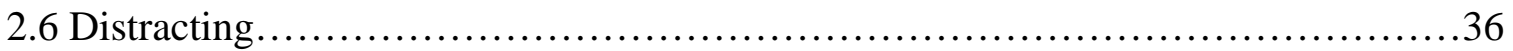

3.1 Cross-Tabulation/Amount of TV Per Week \& Awareness..........................37

3.2 Amount of Television Per Week..............................................37

3.3 Cross-Tabulation of Awareness..............................................37

4.1 Type of Placement...................................................... 38

5.1 Well-Known Television Products............................................38

5.2 Well-Known Film Products...............................................39

6.1 Ethical Considerations....................................................39

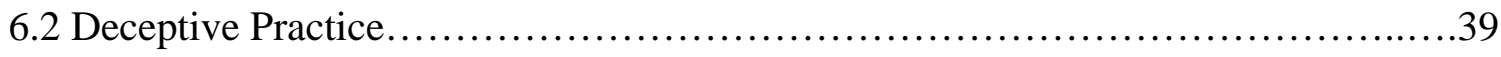

6.3 Cross-Tabulation of Surprise and Deception.................................40

6.4 Cross-Tabulation Aware of Occurrence and Deceptive..........................40 


\section{FIGURES}

F1 Product Placement Spending in Media from 1974-2004.........................43

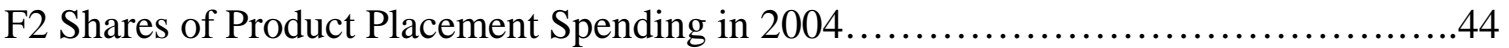

F3 Projected Product Placement Spending from 2004-2009.........................45 


\section{Introduction}

Product placement has become a $\$ 4$ billion industry in films, television and has even made its way into the world of print media such as magazines and novels. This form of advertising partners marketers (who value it for cost-effectively creating consumer awareness) and mass media producers (who rely on it for reducing production costs). Due to the subtlety of the placement embedding and other promotional techniques, audience members are often completely unaware and, therefore, highly susceptible of the practice. The influence is sometimes so powerful that product placement's critics have sought federal regulation of the practice. ${ }^{1}$

\section{Purpose}

It is visible to see how the realm of product placement and integration has become a way of cutting costs for producers as well as a way of promoting products for marketer's. However, many critics argue that there is no intended benefit for the viewing audience. They believe it is a manipulative form of advertising and that product placement jeopardizes artistic integrity. Proponents, on the other hand, argue that the audience is well aware of what they are encountering and that the practice adds a certain “ambience” for the viewers. To further study this issue, the researcher will determine whether students at WVU are aware of product placement, and if so, what their thoughts are on different aspects of this form of advertising.

\section{$\underline{\text { Research Question }}$}

How has product placement evolved over the years and what are the viewing audience's thoughts on the practice?

\footnotetext{
${ }^{1}$ James Karr, "Brand placement: A Review," Journal of Current Issues and Research in Advertising," (Spring 1998): 14-16.
} 


\section{Literature Review}

Product placement can be defined as “the process that integrates an advertiser's product into selected media, most often television and films, for clear visibility.” Although the product is visible, it is often not the focus, as it needs to fit almost seamlessly into the context of a scene or story. Product integration is a special type of product placement in which the advertiser's product is central to the program's plot line. Product placement can be audio, visual or print based ${ }^{2}$.

The term brand placement is used interchangeably with "product placement" in most advertising and marketing literature. For the purpose of this literature review, it will be regarded in the same manner. Brand placement is defined as "a paid product message aimed at influencing movie or television audiences along planned and unobtrusive entry of a branded product into a movie or television show.”3

\section{Overall Trends}

According to PQ Media, there are three main ways in which product placements are paid for or in many cases arranged: paid, in which a financial transaction takes place; barter, which is arranged and the product serves as the form of compensation; and gratis, in which the placement occurs to "strengthen a character's profile, or add richness to the

plot, audio or printed text (see Figure 1)."4 According to Harrison, approximately $10 \%$ of product placement transactions are done through the "pay for placement” model in which corporations pay a considerable fee for the placement. ${ }^{5}$ When a direct payment model is

\footnotetext{
${ }^{2}$ Ibid.

${ }^{3}$ Ibid.

${ }^{4}$ PQ Media Research, www.pqmedia.com, March 2005 results.
} 
used, "visual exposure is the least expensive, verbal mentions are moderately priced and character usage is the most costly."

In correlation with a 2005 study conducted by PQ Media, it was found that over all, the product placement market increased 30.5\% to $\$ 3.46$ billion in 2004, and grew at an overall rate of $16.3 \%$ from 1999 to 2004 . Since the early 1970 's, the overall value of product placement rose at a rate of $10.5 \%{ }^{7}$ Meanwhile, the share of product placement spending on television has risen from $37.1 \%$ in 1974 to $54.3 \%$ in 2004 , with a 10 -point increase in the years from 2001-2004. ${ }^{8}$

In addition, marketers are now turning to other media outlets, i.e., video games and the Internet, which attract 18-to34-year olds. This age group is one of the most sought after by advertisers due to the nature of brand loyalty that these consumers convey. Another key trend is the growth of paid placements as opposed to other means such as barter. The share of paid placements increased from $18 \%$ in 1974 to $29.2 \%$ in 2004. Competing marketers are more willing today to pay for slots in scripts in order to beat out their competitors. As a result of the increased payment method being used, gratis placements, which were popular in the past, accounting for $24.3 \%$ of the market's value in 1974, have become much less frequent, taking up only about $6.6 \%$ of total spending in 2004 (see Figure 2). ${ }^{9}$ Product placement is expected to increase at an overall value of \$3.5 million by 2009 (see Figure 3). ${ }^{10}$

\footnotetext{
${ }^{5}$ Edward Harrison, “Cashing in: E.T. led the way,” Los Angeles Times, 20, Aug. 1999: Calendar section, 25.

${ }^{6}$ Ibid., PQ Media Study.

${ }^{7}$ Ibid.

${ }^{8}$ Ibid.

${ }^{9}$ Ibid.
} 


\section{History and Background Information}

Historically product placement hasn’t existed much in television. Producers tended to use generic products on the set-they didn't want real products to appear in scripted network shows to avoid advertising conflicts that would continue when shows moved into syndication, cable and other outlets. ${ }^{11}$ The driving force behind this form of marketing rests in the fact that advertisers are losing control over the attention of viewers who now so readily skip commercials using Digital Video Recorders or rather DVRs.

A 2004 study by Media Planning Group revealed that 90\% of DVR users skip commercials altogether. ${ }^{12}$ What's worse for the networks is the fact that only $16 \%$ of those watching TV live sit through commercials. Nielsen Media Research notes that nearly $8 \%$ of homes currently have a DVR, but that's expected to increase to 39\% by $2010 .^{13}$ Faced with this obstacle, the networks have searched for new ways to get the ads to the audiences. Along with this, the growth of reality television has brought about change. With unlimited rerun value for reality shows, television producers are seeking payment from marketers to place a name brand product and therefore offset market costs. $^{14}$

\footnotetext{
${ }^{10}$ Ibid.

${ }^{11}$ Wayne Friedman, “Bonanza Remains Elusive,” Television Week, 11 Oct. 2004: 22.

${ }^{12}$ Michael Storey, “Place ad: The line between TV series and infomercial has been crossed,” Arkansas Democrat Gazette, D3.

${ }^{13}$ Ibid.

${ }^{14}$ Ibid.
} 
Motion picture studios have been using marketers' products and advertisements as props in their films for decades. ${ }^{15}$ Rothenberg offered evidence that motion picture studios used product placement before WWI. ${ }^{16}$ The practice increased by the 1930 's, when studios began slowly incorporating the idea of promoting products in movies by sending marketers shot-by-shot breakdowns of scripts with promotional opportunities clearly indicated to these marketers. ${ }^{17}$ By 1939, Metro-Goldwyn became the first studio ever to open a placement office. ${ }^{18}$ In the first documented instance of a movie star's plugging a brand-name product in a Hollywood film, Joan Crawford pours a customer a glass of Jack Daniels liquor in Mildred Pierce (1945). ${ }^{19}$

Product placement expanded slowly until the late 1960’s. During this era, directors began emphasizing reality-based themes in their films and started incorporating actual brand label products and advertising images. ${ }^{20}$ By the 1970’s, movie executives recognized product placement as a way to diminish enormous production and advertising costs during the studios' financial troubles. Faced with decreasing ticket sales and overwhelming film production costs, these executives began to rely on product placement as a means of support for their diminishing budgets. ${ }^{21}$

\footnotetext{
${ }^{15}$ Michael Magiera, "Products in movies: How big a deal,” Advertising Age, 55, no. 4 (June 1991).

${ }^{16}$ Robert Rothenberg, “Critics seek F.T.C. action on product as movie stars,” New York Times, 14, May 1991: D1.

${ }^{17}$ Ibid.

${ }^{18}$ Ibid.

19 Ibid.

${ }^{20}$ Lois Weis, “Products winning movie auditions,” Advertising Age, 56, no. 2 (Dec. 1985): 19-20.

${ }^{21}$ Michael Magiera., "Products in movies: How big a deal,” 55, no.4.
} 
It wasn't until the 1982 movie E.T., however, that marketers fully understood product placements' commercial impact and began to actively seek their own product placements. ${ }^{22}$ When E.T. was in production, Hershey was contacted and asked if it wanted to put money into the film. According to Dennis Eshleman, Hershey product manager, during the first stages of the film, when Universal approached Hershey, they had no idea what the movie title was going to be, but basically liked the premise and decided to put up \$1 million in "promotional money". Within one month of the movies release, the sale of Reese's Pieces skyrocketed an astounding $65 \% .{ }^{23}$ As time passed, the E.T. placement was cited again and again and became the poster child for product placement.

Due to the success of E.T, in 1983, $20^{\text {th }}$ Century Fox became the first Hollywood major to officially and publicly offer manufacturers a specific display of their brandname products in movies. Early in 1984 Fox released Unfaithfully Yours, which featured Dudley Moore walking off a TWA plane. TWA paid Fox at least $\$ 100,000$ for the plug. The frenzy continued when a scene in Cocoon: The Return incorporated Quaker Instant Oatmeal and continued to exist when Short Circuit director John Badham included Alaska Airlines, Apple Computers and Bounty Paper Towels in his film. ${ }^{24}$

By the time the 1990's arrived, the practice of product placement became a common operating procedure. Some examples in the earlier part of this decade included Pamper’s \$50,000 placement fee in Three Men and a Baby, Cuervo Gold’s \$150,000

\footnotetext{
${ }^{22}$ Matthew McCarthy., “Of all the Jim Beam joints,” Chicago Tribune, 18, Aug. 1996: E17.

${ }^{23}$ Roger Shiner, Freedom of Commercial Expression, (NY: Oxford Press, 2003): 102-104.

${ }^{24}$ Ibid., 103.
} 
placement for Tequila Sunrise, and Esso gas’s \$300,000 placement in Days of Thunder. ${ }^{25}$ Some advertisers, such as Fed-Ex, stepped into the role of financial backer, funding $80 \%$ of Cast Away which featured their packages prominently saving the star stranded on a remote island. ${ }^{26}$

\section{Product Placement of Yesterday and Today}

Traditional product placement within programs occurred, with advertisers controlling dialogue and other means to their own advantage. In 1949’s, Man Against Crime series, the Camel cigarette company, who sponsored the show made arrangements with the production staff so that cigarettes were never associated in a "bad" manor; no suggestion was to be made of a narcotic effect; arson and fires were to never be mentioned; no one was allowed to cough; and doctors characters were only to be used in an “admirable light," therefore leaving no impression in the viewer's mind of possible bad side effects of cigarettes. ${ }^{27}$

Through the interdependence of studio executives seeking cost and advertising support and corporate marketers’ desire for product exposure, the practice of product placement has greatly evolved throughout the past few decades. What was at one time a small Hollywood-based industry has become a multi-million dollar enterprise.

Consequently, the original definition of product placement as the manipulation of features of television and movie material for commercial purposes has taken on a whole new meaning and expanded into new media forms, such as the Internet and video games. In addition to standard product placement, Barnow insists that "the American public is

\footnotetext{
${ }^{25}$ Paul McCarthy, “Ad ventures in tinsel town,” Sydney Morning Herald, 5, Jan. 1998: Spectrum Section 8.

${ }^{26}$ James Shaw, “Now starring at a cinema near you,” NZ Marketing Magazine, 20, no. 3 (2001): 35-38.

${ }^{27}$ Ibid., 74.
} 
now being overwhelmed with ads masquerading as news or entertainment through infomercials, promotional music videos being passed off as creative programming, and film and television commercial cross-promotions, including support from news divisions of entertainment companies."28

\section{The Concept of Product Placement}

The practice of product placement is fairly simple to understand. In its original form, stemming from feature films, it "involves incorporating brands into movies in return for money or for some promotion or other consideration.”29 ${ }^{29}$ both television and film, the practice of product placement and the featuring of brands occur in three primary ways. First, the product can be seen in the background of the set, or actually being used. Second, a corporate logo, trademark or other identifying characteristic may be shown. Third, an advertisement, such as a billboard or television commercial may be placed into a scene as "ambiance” in the background. Along with this, a character may verbally mention the brand name or the brand may be referred to without actually mentioning the brand itself. This was the case with a reference made about a "computing company" with a fruit name that signified Apple Computer in Forrest Gump. ${ }^{30}$

\footnotetext{
${ }^{28}$ Edward Barnow., "Tube of Plenty: The Evolution of American Television,” (NY: Oxford Press, 2001): 85.

${ }^{29}$ Stephen J. Gould and Pola B. Gupta, “Consumers' perception of the ethics and acceptability of product placement in movies: Product category and individual differences. Journal of Current Issues and Research in Advertising," 19, no. 1 (1997): 37-50.

${ }^{30}$ Bryan Smith, “Casting product for special effect,” Beverage World, 104 (March 1985): 83-91.
} 


\section{The Process}

The popularity of product placement has triggered a thriving industry of around 100 promotion companies in the U.S. that specialize in this form of advertising. ${ }^{31}$ Placement agents read scripts and meet with set designers to find scenes where their clients' products can be placed in the set or integrated into the script. The objective is to incorporate brands that add realness to the program and that give "subtle exposure" to brand names, and that persuade in an unobtrusive manner. ${ }^{32}$

When a production studio decides it wants to incorporate some type of product or brand into the script, there is a particular protocol that is followed: There is at least one executive dedicated solely to this form of placement per studio. Some of the studios refer to this responsibility as "production resources," while others refer to it directly as "product placement." Any company that plans on including these resources for production purposes must go through the Production Resources or Product Placement Department. ${ }^{33}$ This department serves as the mediator between the filmmakers and the corporate marketers or their agents.

The studio executive's first step is to read the scripts for upcoming films, which are scheduled to go into production. From this point, the executive does a breakdown of potential product placement opportunities. Next, the studio executive places calls to product placement agencies, which represent many of the corporations, which have

\footnotetext{
${ }^{31}$ Deborah Adamson, “Ads in Sheep's Clothing from Beer to Cars: Product Placements in Movies and TV Enriches Artistic, Corporate Partners and Spawns New Industry,” Los Angeles Daily News, 15 Sept. 2000: B1.

${ }^{32}$ Laurie A. Babin and Sheri T. Carder, "Viewer’s Recognition of Brands Placed within a Film," International Journal of Advertising 15, no.12 (January 1999): 140-151.

${ }^{33}$ Ibid., 142.
} 
established an interest in this method of promotion. Then, corporate marketers-who have established offices dedicated to serving their placement-are contacted. ${ }^{34}$

Once the deals are made, the products arrive from one of two places: the placement agency warehouses or directly from the corporations. The total amount of time it takes from the begin to end of this process varies considerably, with some studios starting as much as three months or more in advance of production to others beginning within weeks of shooting. ${ }^{35}$

\section{Contracts}

After deals are made, a contract must be written up to ensure any legal matters are taken into consideration. ${ }^{36}$ (Product placement contracts are usually generated by the studios). Here, the studios use a standard set of contracts, which vary in complexity depending upon the type of placement of what means of compensation is necessary. ${ }^{37}$ (see Appendix A). ${ }^{38}$ Special contracts are sometimes written, especially if the compensation includes a promotion. If a placement agency is involved, it normally only serves as the negotiator of the contract, whereas the final decision lies in the hands of the corporate marketer. ${ }^{39}$ Because the contracts are usually vague, it is almost always agreed upon by both sides that the contracts themselves are not as important as the reputation upon which

\footnotetext{
${ }^{34}$ Ibid.

${ }^{35}$ Ibid.

${ }^{36}$ Rosemary J. Avery, and Rosellina Ferraro., "Verisimilitude or advertising," Journal of Consumer Affairs, 34, no. 2 (Winter 2000): 217-244.

${ }^{37}$ Ibid., 221.

${ }^{38}$ Ibid.

${ }^{39}$ Ibid., 222.
} 
they are based. ${ }^{40}$ Negotiations between the studios and marketers generally focus on the manner in which the products will be portrayed. Scripts are usually reviewed ahead of time and the page(s) where the products will be included are often attached to the contract. $^{41}$

\section{Examples of Product Placement}

In the 1982 movie E.T., although there was no paid product placement, (but rather promotional money), the sale of Reese’s Pieces skyrocketed 65\% after the extra terrestrial ate the pack of candy. In Golden Eye, James Bond drives a BMW Z3 and in Men in Black, Will Smith wears Ray-Ban sunglasses. Again, both the Z3 and Ray-Bans sales_ - of the particular items placed in the movies — increased after the premiere of each film. ${ }^{42}$ This could primarily be a coincidence, but no proof has been able to disprove that the placement themselves gave viewers more of an urge to purchase the items. ${ }^{43}$

However, movies aren't the only form of entertainment where product placement is predominant. In Fox’s popular reality series “American Idol,” judges are seen sipping from their strategically placed Coca-Cola cups. ${ }^{44}$ In one particular episode of the NBC Emmy winning comedy "Friends," the writers incorporated a Pottery Barn table as part of the plot. After the show aired, "the company was sold out of the table for months".

\footnotetext{
${ }^{40}$ Ibid., 224.

${ }^{41}$ Ibid., 238.

${ }^{42}$ Denise DeLorme, "Moviegoers' experiences and interpretations of brands in films revisited," Journal of Advertising, 1999, 2: 74-82.

${ }^{43}$ Ibid.

${ }^{44}$ Ibid., 75.
} 
And in the ABC soap opera “All My Children," they at one time dedicated an entire story line (that lasted for more than one episode) to Revlon makeup. ${ }^{45}$

Along with product placement in films and television shows, there are even some instances, which parodies of this form of advertising are used: In the 1992 Saturday Night Live spin-off Wayne's World the main characters dedicate a montogue to the oversaturation of name brand products such as Pepsi, Reebok, Doritos, Pizza Hut and Nuprin. In the 2000 movie Josie and the Pussycats, members of the band are seen throughout the movie drinking Evian water, eating McDonald’s and applying Revlon makeup. In the 2001 futuristic film Minority Report, billboards talk specifically to you and the Gap has robotic employees that remember your name and previous purchases.

\section{Benefits of Product Placement and Those Who Support It}

While it's pretty clear to see what the advantages of product placement are to directors and advertising agencies, it's a bit more vague to interpret how the consumer is benefited, if at all. At the most general level, the ad agency may reduce prop costs by a quarter to a third through a trade of product use for the placement. Arguments are often made that these savings allow for improvements in "product values” by helping support longer shooting schedules or enhancing lighting, sound quality or musical numbers. ${ }^{46}$

For marketers, there are numerous benefits that come along with the placement. For one, unlike television commercials that can be avoided altogether, product placement in television shows and movies usually captures the audience at hand. ${ }^{47}$ Furthermore,

\footnotetext{
${ }^{45}$ Ibid., 82.

${ }^{46}$ Beatrice Branswell, "Subliminal advertising: Communications places products on Quebec TV shows in exchange for services,” Montreal Gazette, 18 May 2002: E3.

${ }^{47}$ When is a prop not a prop?, “The advantages of product placement,” Sports Marketing, 19 Sept. 2001:
} 14. 
cost efficiencies are "considerable" in comparison to paid advertising. Many of the studios see this as the primary benefit of placements. These cost-savings are realized in the props, set decorations and locations which are sometimes provided for free and which ultimately, in most cases, end up on screen. These items can range anywhere from large items such as cars and boats to smaller items such as televisions, clothing and sunglasses. Such cost-savings can be substantial as these items would otherwise have to be purchased or rented.

Prop rental typically costs 10\% of an item's value the first week and 5\% each week following. The paid placement averages around \$50,000 that in some cases might not even buy a one-time 30 -second placement on prime time television. ${ }^{48}$ Lastly, this form of advertising can be long lasting as well as far-reaching. Films and television programs are usually distributed across the world and can retain very long shelf lives in re-runs and video distribution. ${ }^{49}$

Aside from cutting costs, Sawyer suggests "awareness is the most likely outcome of product placement."50 Television programs are generally watched in their entirety, whereas TV ads are often skipped. For exposed product placement, the length and frequency of exposure "maximizes awareness, as well as the vividness of the scene and the integration of the product placement in the story."51 Sawyer further develops this idea by referring to the film "Raising Arizona."

\footnotetext{
${ }^{48}$ Ibid.

${ }^{49}$ Ibid.

${ }^{50}$ Alan G. Sawyer, "Possible psychological processes underlying the effectiveness of brand placements," International Journal of Advertising, (2006): 25.

${ }^{51}$ Ibid., 110.
} 
In this film, there were several instances of brand placement but the only placement that increased brand recall was Huggies. This was apparently due to the fact that the brand was verbally referred to, the package was shown for 36 seconds and the product was the focus of many parts of the movie. ${ }^{52}$ The author concedes, "even if there in no explicit memory of the fact that a brand was seen in a movie or any other medium, research on implicit memory shows that a consumer's choice behavior may still be influenced by product placement exposure."53 Frequent exposure can also assist in influencing judgments.

Consumers are likely to use an "availability heuristic,” which is the process of referring to specific examples or events in order to from biased judgments. As a result, frequent television users overestimate the extent of such occupations as doctors, lawyers and policemen. ${ }^{54}$ Moreover, fictional messages and well-known characters may influence attitudes when viewers are drawn into the plot and identify with a person or situation in the story. In such cases, the audience may feel that it has had a personal experience with the story's events and objects, including product placement, and this experience may influence attitudes. ${ }^{55}$

\section{Under Fire: A Critics Point of View}

From a producer's point of view, product placement is a great way to reduce the budget. From an advertiser's perspective it is a successful way of marketing a brand. One example cited of the effectiveness of product placement involved the sunglass

\footnotetext{
${ }^{52}$ Ibid.

${ }^{53}$ Ibid.

${ }^{54}$ Ibid., 111.

${ }^{55}$ Ibid., 112.
} 
company Ray-Ban. The sales of its Wayfarer model sunglasses tripled the year after Tom Cruise wore them in Risky Business while sales of its Aviator model increased 40\% in the seven months after Cruise wore them in Top Gun. However, there are not many benefits to consumers in the general form of product placement. Tastefully done, the placement may add a realistic quality to a scene or situation, but at the same time demands a certain attention to be drawn to the product.

As John Barnard, CEO of the UK’s largest placement agency, the New Media Group puts it, "You are trying to sink messages into consumers’ minds subconsciously, if you are too obvious, the audience may feel it is being plugged...”56 When referring to the act of product placement or integration, the question has been raised as to whether or not it is a form of deception. As proponents of the practice have stated time and time again, a good placement should be "seamless" and "organic" to the script.

On the other end of the spectrum, it has been disputed that if this form of advertising is performed in such a sensitive manner and blends in so seamlessly, it tends to be misinterpreted and therefore deceives and in some cases, is even considered "subliminal" in manner. Treimer and Simonson define subliminal perception (or stimulation) as any word, image, or sound that is not perceived within the normal range of consciousness, but that makes an impression on the mind. ${ }^{57}$ This phenomenon involves words or pictures that are flashed so quickly that the eye cannot transmit to the

\footnotetext{
${ }^{56}$ Maggie Cowlett, "Public relations: Make it into the movies-Once a dirty word, now product placement in major films is big business,” Europe Intelligence, 5, Aug. 2000: 29.

${ }^{57}$ Margaret Treimer and Michael Simonson, “Subliminal Messages, Persuasion, and Behavior Change," The Journal of Social Psychology, August 1987: 563.
} 
conscious brain, or words spoken at such a volume that they evoke no conscious

memory. ${ }^{58}$

In order to understand the unconscious mind, Moore believes we should first define awareness. The author states that one way to define "awareness" is by simply asking observers whether or not they are aware of the stimulus. If the observer denies any awareness, then the stimulus is by definition, below an awareness threshold. Using this approach, unconscious perception consists of demonstrating that observers can be affected by stimuli whose presence they do not report. ${ }^{59}$

\section{Persuasive, Manipulative or Neither}

According to Rothenburg, most advertising messages are a mix of informational and persuasive content. Messages in the form of persuasion can be seen in two different forms. First, the advertiser chooses specific attributes of each product or service to include in the message. ${ }^{60}$ Second, the message may indicate how consumers will think or feel once they have decided to buy the product. Consumers make the decision about what to buy based on how the product or service, as described, will fulfill their own wants and needs. ${ }^{61}$

The theory of persuasion suggests persuasion is a process by which people use messages to influence others. While persuasion typically uses information, the emphasis in a persuasive message is on influencing the receiver (rather than merely providing

\footnotetext{
${ }^{58}$ Ibid.

${ }^{59}$ Timothy E. Moore, “Subliminal Perception: Facts and Fallacies,” The Skeptical Inquirer, (Spring 1992): 15-16.

${ }^{60}$ Robert Rothenburg, “Marketing’s borders blurred by product placement revival,” Advertsing Age 16, no. 1 (September 2001).

${ }^{61}$ Ibid.
} 
information and letting the receiver make up his own mind). Persuasion is the act of attempting to change minds or get people to act. ${ }^{62}$ Persuasion is similar to subliminal projection in that it "suggests something a bit distasteful, something more or less hidden, unfair; a subtle or not so subtle playing on manipulating people, perhaps by appealing to emotion”. 63

However, Phillips states that manipulative advertisements are sometimes referred to as being persuasive. He goes on to state that the term persuasion is too broad to capture the traits that make advertising objectionable. ${ }^{64}$ In ordinary usage, persuasion includes situations in which desired behavior is produced by means of rational argument. The author defines persuasion as “a deliberate and successful attempt by one person to get another person by appeals to reason to freely accept beliefs, attitudes, values, intentions, or actions.”65

As this definition implies, persuasion can be associated with rational persuasion whereas manipulation can be seen in the form of non-rational persuasion. ${ }^{66}$ The author concludes by saying, "the essence of rational persuasion is that it induces change by convincing a person through the merit of the reasons put forward." ${ }^{\circ 7}$ When this issue is

\footnotetext{
${ }^{62}$ Kenneth E. Andersen, Persuasion Theory and Practice (MA: Allyn and Bacon INC., 1971): 51.

${ }^{63}$ Ibid., 63.

${ }^{64}$ Michael J. Phillips, Ethics and Manipulation in Advertising, (CT: Quorum Books, 1997): 15-16.

${ }^{65}$ Ibid.

${ }^{66}$ Ibid.

${ }^{67}$ Ibid., 16.
} 
brought up, advocates of the practice often argue that consumers are increasingly "savvy" and aware that the placements are likely to be "buried" anywhere. ${ }^{68}$

Acknowledging the vast influence of movies and audiences, movie critics and consumer advocates have warned of the dangerous nature of product placement. ${ }^{69}$ Social critics have sought government intervention or industry self-restraint since right after the debut of Reese's Pieces unforgettable appearance in E.T. ${ }^{70}$ Shortly after this placement, in 1989, an attack arose on the act of product placement. ${ }^{71}$

Representative Tom Luken (D.-Ohio) wanted to determine if product placement in movies was a form of paid advertising. And in the case of tobacco companies if it was paid advertising, "did that violate the congressional intent of keeping cigarette ads off the nation’s airways.” Luken asked U.S. Attorney General Richard Thornburgh to investigate whether the Philip Morris Company broke federal laws by paying film makers to display their cigarettes in feature films. ${ }^{72}$ In his request letter Luken referred to instances in which cigarette companies paid to have their products placed into moviesSuperman II, Supergirl, and James Bond's License to Kill. ${ }^{73}$

According to documents provided by Luken, in September 1988 "Philip Morris paid \$350,000 for placement of Lark cigarettes in the Bond film. It also paid \$42,500 in 1979 for placement of its Marlboro brand in Superman II." Because the tobacco ads had to include federally mandated health warnings, Luken believed any ads placed in these

\footnotetext{
${ }^{68}$ Ibid.

${ }^{69}$ Mitchell C. Miller., “Hollywood the ad,” Atlantic Monthly, 6 April 1990: 41.

${ }^{70}$ Ibid., 43.

${ }^{71}$ Ibid.

${ }^{72}$ Susan W. Colford, “Tobacco critic opens new front,” Advertising Age, 1989, 6.11-14.

${ }^{73}$ Ibid., 11.
} 
movies which lacked the warnings violated the Federal Cigarette Labeling and Advertising Act. $^{74}$

In defense to Luken's accusations, Steve Weiss, manager of media relations at Philip Morris USA, said "placement was not advertising but product promotion, and that the money for the "so-called placements," "probably came from the promotion budgets, not from the advertising budgets." ${ }^{, 75}$ Unfortunately for Luken, no federal legislation emerged from this. Both the Federal Trade Commission and the Federal Communications Commission declined to any rule-making aimed at restrictions on product placement in movies. $^{76}$

\section{Laws and Federal Regulations}

When the situation arises in which an advertisement is called into account as being manipulative, the advertising agency must decipher whether the adverting code of ethics was followed. According to the advertising code of ethics: advertising shall tell the truth, and shall reveal significant facts, the omission of which would mislead the public; advertising claims shall be substantiated by evidence in possession of the advertiser and advertising agency, prior to making such claims; advertising shall refrain from making false, misleading, or unsubstantiated statements or claims about a competitor or his/her products or services; advertising shall not offer products or services for sale unless such offer constitutes a bona fide effort to sell the advertising products or services and is not a device to switch consumers to other goods or services, usually higher priced; advertising of guarantees and warranties shall be explicit, with sufficient

\footnotetext{
${ }^{74}$ Ibid., 13.

${ }^{75}$ Ibid., 12.

${ }^{76}$ Ibid.
} 
information to apprise consumers of their principle terms and limitations or, when space and time restrictions preclude such disclosures, the advertisement should clearly reveal where the full text of guarantee or warranty can be examined before purchase; advertising shall avoid price claims which are false or misleading, or saving claims which do not offer provable savings; advertising containing testimonials shall be limited to those of competent witnesses who are reflecting a real and honest opinion or experience; advertising shall be free of statements, illustrations or implications which are offensive to good taste or public decency; advertising shall be free of statements, illustrations or implications which are offensive to good taste or public decency." ${ }^{\text {77 }}$

When the advertising code of ethics is not enforced by an agency, the government comes into play. "The role of the government is not to suppress, destroy or disable advertising”. However, the government does have a dual responsibility when it comes to advertising. ${ }^{78}$ This responsibility includes protecting commercial speech (i.e., protecting advertisers' and advertising agencies' right to communicate information), and also protecting consumers from speech that can cause them harm such as deceptive advertising. ${ }^{79}$

The Federal Trade Commission was created in the early 1900's in order to prevent unfair competition as well as "monitor and deter false, fraudulent, misleading, or deceptive advertising in interstate commerce." ${ }^{80}$ The FTC has jurisdiction over

\footnotetext{
${ }^{77}$ Roger A. Shiner, Freedom of Commercial Expression, (NY: Oxford Press, 2003): 111.

${ }^{78}$ Kim Sheehan, Controversies in Contemporary Advertising, (CA: Sage Publications, Inc., 2003): 51.

${ }^{79}$ Ibid.

${ }^{80}$ J.T. Russell and R. Lane, Kleppner's Advertising Procedures, (NJ: Prentice Hall, 2002): 43.
} 
misleading advertising because it is considered an unfair trade practice. ${ }^{81}$ The FTC clearly defines advertising as deceptive "when there is a representation in the advertisement (i.e., and image or description) or an omission in the advertisement (i.e., leaving out an important piece of information) that is misleading.",82

The FTC has several ways of addressing deceptive advertising. If the FTC finds that an advertisement is deceptive, the advertiser may be asked to sign a consent decree. This is a document that does not admit to deception, but rather agrees to stop running the advertisement. ${ }^{83}$ If an advertiser chooses not to sign the decree, "the FTC may fine the advertiser, order the advertiser to stop running the advertisements an/or require the advertiser to run corrective advertisements". ${ }^{84}$

In the beginning of the $20^{\text {th }}$ century, the U.S. Supreme Court declared that advertising was not protected under the First Amendment. That meant any time an entity had an issue with some form of advertising communication, the advertisement could be banned legally. ${ }^{85}$ In the 1960 's, the Supreme Court began to realize that certain types of advertisements should be protected under the Constitution. ${ }^{86}$ Today, First Amendment law has evolved to where it is apparent that the right to communicate information of public interest is not unrestricted in commercial settings. ${ }^{87}$

\footnotetext{
${ }^{81}$ Ibid.

${ }^{82}$ Kim Sheehan, Controversies in Contemporary Advertising, 57.

${ }^{83}$ Ibid.

${ }^{84}$ Ibid.

${ }^{85}$ Ibid., 52.

${ }^{86}$ Ibid., 53.

${ }^{87}$ Ibid., 52.
} 
Placements in television programs are generally unpaid because the Federal Communications Commission (FCC) has sponsorship identification rules governing paid placements in this medium. The regulation specifies that "when brands are mentioned or appear in television programs for a fee, that information must be disclosed during the program.” Many companies have found a way around these rules, however, by simply supplying products free of charge to program directors. ${ }^{88}$

Policy issues surrounding product placement in movies and television have been debated by both lawyers and consumer advocates from the very beginning. Studies indicate that the practice in movies is already well established, but few studies have focused on the medium of television. According to Nielsen Media research, the average American household television set is on for 7.2 hours a day. ${ }^{89}$ Because viewers of television programs often watch favorite shows over extended periods of time, they can become deeply involved in the plot lines. The high level of constant repetition and exposure in television viewing is troublesome because brand loyalty is significantly related to the frequency of brand exposure. In support of this concern, another stream of communications research shows that "television is a symbolic environment that is extremely persuasive in forming cultural values.",90

What the industry calls "integrated" advertising, "seamless" advertising or "embedded" advertising, viewers may think of as sneaky advertising. ${ }^{91}$ The goal is to

\footnotetext{
${ }^{88}$ Stacy Vollmers and Richard W. Mizerski, “A Review and Investigation into the Effectiveness of Product Placements in Films," Proceedings of the 1994 Conference of the American Academy of Advertising.

${ }^{89}$ Nielson Media Research, “Report on Television, New York: Nielsen Media Research, 1999.

90 "A Review and Investigation into the Effectiveness of Product Placement in Films.”

${ }^{91}$ Joanne Ostrow, “When Ads are the Stars,” The Denver Post, 28 Nov. 2004: F1.
} 
bring brand labels out in the front and center to become part of the show instead of merely being a decoration in the background. The intended effect is to void the line between art and commerce so that marketing and entertainment become one. ${ }^{92} \mathrm{TV}$ script writers, producers, networks and advertisers are teaming up to disguise advertising as entertainment, or at least to blur the distinction. ${ }^{93}$

Legal scholars have debated whether or not the appearance or mention of branded products, either subtly or overtly, in movies and television designed for entertainment purposes constitutes commercial speech. However, The Federal Communications Commission’s (FCC) sponsorship identification rules require that television shows disclose their list of sponsors if there is more than a passing reference made to particular products or services. The rules state the following in part:

When a standard broadcast station transmits any matter for which money, services, or other valuable consideration is either directly or indirectly paid or promised to, or charged or received by, such station, the station shall broadcast an announcement that such matter is sponsored, paid for, or furnished, either in whole or in part, and by whom or on whose behalf such consideration was supplied: Provided, however, That "service or other valuable consideration" shall not include any service or property furnished without charge or at a nominal charge for use on, or for an identification in a broadcast of any person, product, service, trademark, or brand name beyond an identification which is reasonably related to the use of such service or property on the broadcast.

According to the Von Restorff effect, "any technique that increases the novelty of particular products or leads them to be unexpected enhances the recall of those products." ${ }^{94}$ Therefore, when a familiar brand is seen in an unexpected context, the effect will be positive in terms of product awareness and recall. People recall brands shown in

\footnotetext{
${ }^{92}$ Ibid.

${ }^{93}$ Ibid.

${ }^{94}$ Stanley Balasubramanian, "Beyond Advertising and Publicity,” 29.
} 
films and some researchers have found that prominent product placements perform better than television ads in creating brand recall among consumers. ${ }^{95}$

According to Frank Zazza, chief executive of iTVX, a company that measures the value of product placement, predicts "the practice will become a billion-dollar industry within the next year.” The biggest product placement shows are "The Apprentice,” “Survivor,” "Extreme Makeover: Home Edition,” and Fox’s “American Idol.”96

Critics such as Commercial Alert would like to see this million-dollar industry take on more accountability. In September 2003, Commercial Alert, a public advocacy group called on the FTC to require that product placements be promptly identified with a superimposed message like "advertisement" as they occur during a program. ${ }^{97}$

In its response, the commission wrote in a letter to Gary Ruskin, executive director at Commercial Alert, that even though "there may be instances in which the line between advertising and programming may be blurred,” additional regulation was unnecessary because "the existing statutory and regulatory framework provides sufficient tools for challenging deceptive practices."${ }^{, 98}$

Although many researchers are now focusing their attention on "product integration,” relatively little is known about the perceptions of those ordinary individuals who, research suggests, are exposed to thousands of advertisements each day. Yet, understanding consumers is important for both practical and theoretical purposes. ${ }^{99}$

\footnotetext{
${ }^{95}$ Ibid.

${ }^{96}$ Ibid.

${ }^{97}$ Mark Laswell, “Safety Embedded,” Broadcasting and Cable, 134, no. 43 (2004): 18.

${ }^{98}$ Ibid.

${ }^{99}$ Hyunsoo Park and Michael F. Weigold, "Advertising Ethics: South Korean and American Perceptions and Ideology,” Journal of Mass Media Ethics,” no. 14 (1999): 2.
} 
Ultimately, the consumer decides what is permissible in advertising, either directly (through purchase behavior) or indirectly (demands on regulatory agencies). ${ }^{100}$

\section{Previous Studies Dedicated to the Practice}

In each of their studies, Blumer (1933) and Custen (1980) emphasized the importance of the moviegoer’s perception on brand placement. Blumer (1933) focused more so on the influence of movies on audience behavior. He found movies influenced a wide range of behaviors, including “childhood play, imitations of adult conduct, emotional experiences, and lifestyles”. ${ }^{101}$ In the 1960’s, Marine recruits at Camp Pendelton who were extras on the set of a movie were asked by the movie director their reasons for enlisting in the military. Approximately half of them said that they had been inspired by John Wayne movies. ${ }^{102}$

While this may not be the most in-depth of studies, it shows the how perceptions of characters can turn into ones realities. The author of the Vietnam movie Born on the Fourth of July states he saw the movie The Sands of Iwo Jima, and then started to play war games with his childhood friends. ${ }^{103}$ He stated that those childhood experiences influenced him to enlist in the Marines. Blumer concluded "because movies shape and influence audience interpretations of everyday social life, they are a training vehicle for the socialization process". 104

\footnotetext{
100 Ibid.

${ }^{101}$ Denise DeLorme, Journal of Advertising, 28.

102 Ibid.

103 Stanley Balasurbramanian, “Beyond Ad and Publicity,” 29.

${ }^{104}$ Denise DeLorme, Journal of Advertising, 28.
} 
In 1999, DeLorme and Reid conducted a study to provide an understanding of how brand props were interpreted by moviegoers. In this study, they used sample groups that included both frequent and infrequent moviegoers in two age brackets. The first group consisted of 18-to-21 years old and the second group, 35-to-48 years old. The difference in age groups "was important because it afforded an age contrast needed for category saturation”. ${ }^{105}$ Three main themes arose from this analysis; appreciating realism (props assisted in suspension of disbelief and added to movie realism); noticing familiar brands (noticed and liked familiar branded products, enhanced realism); and relating to characters (comparison of characters with own lives). ${ }^{106}$

The subject groups considered themselves immune to the persuasive power of brands encountered in movies. They believed the appearance of brand props in movies were neither deceptive, nor manipulative. Regardless of age or movie going frequency, moviegoers were attuned to familiar brands of products and services. ${ }^{107}$

It was stated that in both studies, moviegoers indicated the relationship with characters strengthened, and involvement in and enjoyment of the movie increased, if “their brands” were being used by a movie character or even featured in a scene. This association, brand familiarity and character identification is supportive and interrelated with the third major theme that emerged from their study; relating to characters. To moviegoers in both studies, brand placement was significant in that it provided relevant information about a character, it told something about "their" character.

\footnotetext{
${ }^{105}$ Ibid.

${ }^{106}$ Stanley Balasurbramanian, "Beyond Ad and Publicity,” 29.

${ }^{107}$ Ibid.
} 
The participants in the studies said that "in addition to strengthening a perception of characters in the movie, brand placement enabled moviegoers to empathize with and relate to characters and further involved themselves in the movie.”108 Character association not only enhanced the entertainment value of movies, but also contributed to moviegoers’ own self-perception.

To the younger moviegoers (18-to-21 age group), brand props were associated with feeling of emotional security and belonging. They had grown up with brands in movies and were accustomed to the practice. They reported when a brand is present in a movie, they just take it for granted and "overlook it because it’s so prevalent.” In addition, the younger people had grown up with much more marketing and advertising in general. Therefore they expected to encounter brands; it was just something they accepted as a part of present day movies. ${ }^{109}$

In the view of the younger group, brands in movies strengthened the sharing of experiences between moviegoers and characters, between moviegoers and other moviegoers, and between moviegoers and other elements of society. To them, brand props took on significance, beyond the context of a particular movie, because they provide a common bond for self and group identification. Encountered brands were not seen as symbols of change by the younger moviegoers; they were associated with belonging, comfort, and security. ${ }^{110}$

The results from DeLorme and Reid's 1999 study showed how the differences varied depending on the age group studied. To older moviegoers, brands in movies may be seen

\footnotetext{
${ }^{108}$ Ibid.

${ }^{109}$ Ibid.

${ }^{110}$ Ibid.
} 
as representative of a transition or shift in the movie viewing experience from a "sacred" to a commercial event; to younger moviegoers, the distinction between "sacred" and commercial may be nonexistent. ${ }^{111}$

\section{Issues Surrounding Product Placement}

The practice of product placement has expanded so thoroughly that it has based an entire industry all of its own. While the exact size of the industry is hard to measure, observers have speculated the industry size to be in a range between $\$ 50$ million and $\$ 4$ billion a year. ${ }^{112}$ Annual fees paid to specialty product placement agencies range from tens of thousands of dollars a year for a small or emerging brand to a few million a year for a major automobile maker. ${ }^{113}$

The industry even has its own association, Entertainment Marketing Association (EMA). EMA is made up of a group of constituents that hold a vested interest in the practice: (1) the corporations and manufacturers that are looking to get their brands placed into entertainment vehicles, (2) the studios and production companies that are looking to defray costs by having products placed into their projects, and (3) the product placement agency, which may be either a specialty agency representing a mixture of clients looking for placements or a more general advertising or public relations firm that offers placement services to its clients. EMA follows a 12-point "Code of Standards and Ethics” to guide its members (see Appendix C). While EMA's Code does not directly incorporate social responsibility or artistic rights issues, it is apparent through the code

\footnotetext{
${ }^{111}$ Ibid.

${ }^{112}$ Edward Harrison, “Cashing in: E.T. led the way,” Los Angeles Times, 4 Aug. 1999: Calendar section, 25.

${ }^{113}$ Ibid.
} 
that there is a concern for product placement to be performed in a sensitive and responsible manner. ${ }^{114}$

Not only has the concept of product placement become a predominant standard over the past few decades, but another form is on the rise: product integration. As a Time magazine report noted:

Product placement used to be simpler. Jerry Seinfield gave shout-outs to Snapple and Junior Mints (gratis) to give his sitcom veri-similitude. The Price is Right still pitches bedroom sets and floor wax. But after Survivor's success, "product integration” (a step past mere placement) is taking in-show advertising to a new level of sophistication and stealth. Products are becoming part of the show, be it the Taco Bell that's the site of a "murder" investigation on a new reality show or an SUV used in a TV-staged transcontinental race. And producers and advertisers are getting cozier than at any time since the days of Texaco Star Theater. ${ }^{115}$

Today, network executives have new demands: “They have asked for and received integration into the context of television shows in return for their spending”. ${ }^{116}$ During “Survivor's” first season, about a million dollars of advertising was linked to product placements. As the second season began in The Australian Outback, product integration had become such a common thread of the series, the show's executive producer has been quoted as replying that "the products have become the adventure's $17^{\text {th }}$ character.”

An innovation in television advertising occurred last spring when a brand-name box of crackers appeared on the CBS sitcom "Yes, Dear” for around 20 seconds. ${ }^{117}$

\footnotetext{
114 Thomas L. Stanley, “The hard sell,” Electronic Media, 29 April 2002: 12-14.

115 James Poniewozik, “This plugs for you,” Time, 18 June 2001: 76.

116 Thomas L. Stanley, “The hard sell,” 13.

${ }^{117}$ Kortney Stringer, "Product placements creep into TV shows, movies for children,” Detroit Free Press, 26, Feb. 2006: Entertainment Section.
} 
However, the box of Kellogg's Club crackers wasn't in the typical product placement form. The image had been digitally created to rest on top a coffee table and inserted after the scene was filmed. This is the latest advancement in brand placement, which critics consider "stealth advertising". 118 The "Yes, Dear" episode in April 2005 marked the first, but certainly not the last commercial use of a patent pending innovation known as Digital Brand Integration, or DBI, developed by New York-based Marathon Ventures, and grew out of a market deal with CBS. ${ }^{119}$

Digital product placement is not the only new technique advertisers are slyly incorporating into television. In a new marketing scheme, KFC has created a commercial with an interactive catch: TV viewers have to replay it in slow motion in order to interpret a code and get a $\$ 1$ off coupon. ${ }^{120}$ Some advertisers are even going to the extreme of hiring a celebrity from a hit show to advertise their product during the commercial break. As viewers' with DVR's are fast-forwarding through the commercial segment, once they see the character, they will in most cases, hit play assuming the break is over. By the time they've done this and realized it is not the program, they have already watched the commercial. ${ }^{121}$

Aside from the area of digital technology and trickery, the most basic form of product placement is also finding its way into a venue that has been considered a taboo hiding place in the past: children's movies. In February, 2006, Curious George, a movie for young children, opened in theaters and contained product placements for Volkswagen

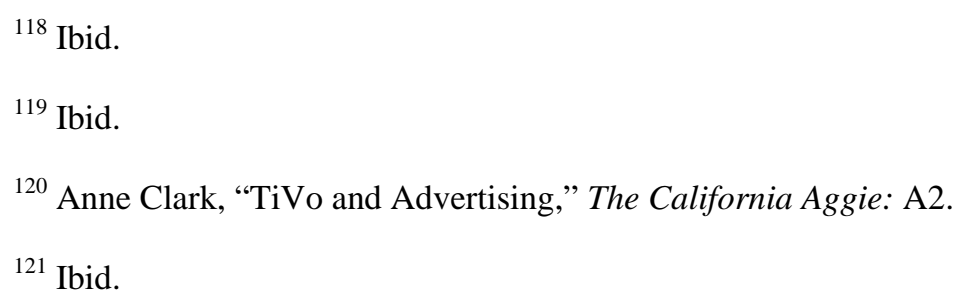


and Dole. In one scene, Curious George takes a rest on a Dole crate and in another, the Man with the Yellow Hat drives a Volkswagen. ${ }^{122}$

This once casual practice has grown into a billion dollar industry. Despite its growth, it is only within the last decade that research on placing name brand products into television shows has and movies has begun. Because advertisers are constantly trying to find new and innovative ways to reach their audiences, the arena of product placement has only just begun. As long as the public doesn’t grow tired of the practice it appears as if product placement has a bright future ahead of itself

\section{Hypotheses}

H1: Viewers who watch the largest amounts of television will be more aware of product placement than any other group.

H2: Product placement will be recognized in the form of consumables more so than any other type of placement.

H3: Product placement in both television shows and movies will be recognized by the viewer as a well-known product.

H4: Product placement will be regarded as an ethical practice in television shows and movies.

\section{Methodology}

Product placement represents the continued blurring of entertainment and selling. Because of this blurring effect, it may appear that "viewers are taking a backseat while advertisers are calling the shots."123 Instances of product placement can be found in a variety of media entertainment offerings including television shows, videos, and movies,

\footnotetext{
122 “Product placements creep into TV shows,” Entertainment.

${ }^{123}$ Claire Atkinson and Jon Fine, “Nielsen Plumbs Product Placement,” Advertising Age, no. 75 (2004): 47.
} 
with this form of advertising considered by many as representing the "new genre of marketing tools.” The present study attempted to expand upon prior research by exploring how aware students at West Virginia University are of the practice and what their thoughts are on it as well. For the purpose of this quantitative study, the researcher developed a 29-question survey dealing with product placement and dispersed it to a total of 385 students at West Virginia University.

According to Berger, surveys can serve a particular importance because "they obtain information that can be quantified and analyzed statistically and thus can reach a higher degree of precision about the group being studied” that other forms of research cannot duplicate. ${ }^{124}$ The data from surveys can also be "summarized in such a way that readers are able to see, rather quickly, what the data reveal about the population being studied." 125 Finally, the researcher chose to conduct a survey style interview rather than a depth interview because this form of interviewing is generally shorter and more structured so information can be gathered to make valid generalizations about the population being studied; self-administered questionnaires are an inexpensive approach; and there tends to be no interviewer bias to worry about.

The questionnaire was administered to 385 students in six classrooms at West Virginia University from the dates of Thursday, February 23 to Thursday, March 9. Along with a cover letter detailing the purpose of the study, the researcher explained to the cluster sample, the importance of their help. Of the 385 surveys that were distributed, a total of 385 were returned. The researcher, however, had to discard 15 of the surveys due to incompleteness.

\footnotetext{
${ }^{124}$ Arthur Asa Berger, Media and Communication Research Methods: An Introduction to Qualitative and Quantitative Approaches, (CA: Sage Publications): 188-205.

125 Ibid., 189.
} 
The questionnaire consisted of two sections. The first portion was divided into multiple choice questions that included categories pertaining to demographics, viewing habits and lastly, thoughts on product placement such as artistic integrity and ethical considerations. The second section contained paired attitudinal questions with answers in the form of a Likert Scale ranging from 1 "strongly agree” to 5 "strongly disagree.” These questions were used as somewhat of a buffer to ascertain whether the respondents were attentive to the questions and to determine if thoughts about product placement in film and television are regarded in the same manner.

When conducting this type of research, the most often used level of confidence is 95\% and, indeed, was used for this study. This level was incorporated because, according to Berger, "a general guideline is the point of estimation for a proportion in surveys of 350 people to have a sampling error of plus or minus two.”126

Each of the surveys was entered into the SPSS system, which was used to determine frequencies and cross-tabulations within the data. From running statistics with the help of this program, it was then determined whether or not the researchers four hypotheses were accepted or rejected.

\section{$\underline{\text { Results and Discussion }}$}

Before discussing the results of the hypotheses, the researcher believes it is important to address a few fundamental aspects of the survey results. Of the 370 respondents, about half were male and half female (see Table 1.1). The majority of the respondents were between the ages of 18-to-20, with the next highest falling under the age group of 21-to-23 and a very small portion were 24-years-of -age or older

\footnotetext{
${ }^{126}$ Ibid., 205.
} 
(see Table 1.2). The highest percentage of respondents stated they watch television with either friends or family, while a much smaller proportion watch it alone (see Table 1.3).

Table 1.1

\begin{tabular}{|ll|r|r|r|r|}
\hline & & & & \multicolumn{2}{c|}{$\begin{array}{c}\text { Cumulative } \\
\text { Percent }\end{array}$} \\
\hline Valid & MALE & 191 & 51.6 & 51.6 & 51.6 \\
& FEMALE & 179 & 48.4 & 48.4 & 100.0 \\
& Total & 370 & 100.0 & 100.0 & \\
\hline
\end{tabular}

Table 1.2

\begin{tabular}{|c|c|c|c|c|c|}
\hline \multicolumn{2}{|c|}{ AGE } & Frequency & Percent & Valid Percent & Cumulative Percent \\
\hline Valid & $18-20$ & 270 & 73.0 & 73.0 & 73.0 \\
\hline & $21-23$ & 86 & 23.2 & 23.2 & 96.2 \\
\hline & $24-26$ & 9 & 2.4 & 2.4 & 98.6 \\
\hline & OTHER & 5 & 1.4 & 1.4 & 100.0 \\
\hline & Total & 370 & 100.0 & 100.0 & \\
\hline
\end{tabular}

Table 1.3

\begin{tabular}{|c|c|c|c|c|c|}
\hline & & Frequency & Percent & Valid Percent & $\begin{array}{c}\text { Cumulative } \\
\text { Percent }\end{array}$ \\
\hline \multirow[t]{4}{*}{ Valid } & ALONE & 112 & 30.3 & 30.3 & 30.3 \\
\hline & WITH FRIENDS/FAMILY & 245 & 66.2 & 66.2 & 96.5 \\
\hline & OTHER & 13 & 3.5 & 3.5 & 100.0 \\
\hline & Total & 370 & 100.0 & 100.0 & \\
\hline
\end{tabular}

From the different genres of television included in the survey, it was discovered that the highest number of respondents watch sports most often, with reality-based television coming in as the second most watched form of television. News programming made up the smallest portion from those surveyed (see Table 2.1). What is interesting and should be noted is that a high proportion $62.4 \%$ of the group believe the type of programming they watch "most often” contains some form of product placement (see Table 2.2). From Table 2.1, it can be seen that the smallest percentage of students watch news programming, which happens to be one form of television that does not often include product placement. Therefore, if a larger percentage of respondents stated that 
they watch news related programs "most often," the results may have been different.

Tying into these results, most of the respondents believe that product placement should not be incorporated into educational or news related programming (see Table 2.3).

Table 2.1

\begin{tabular}{|c|c|c|c|c|c|}
\hline \multicolumn{2}{|c|}{ TV PROGRAMS } & Frequency & Percent & Valid Percent & $\begin{array}{c}\text { Cumulative } \\
\text { Percent }\end{array}$ \\
\hline \multirow[t]{7}{*}{ Valid } & NEWS & 17 & 4.6 & 4.6 & 4.6 \\
\hline & SPORTS & 127 & 34.3 & 34.3 & 38.9 \\
\hline & REALITY & 75 & 20.3 & 20.3 & 59.2 \\
\hline & DRAMA & 46 & 12.4 & 12.4 & 71.6 \\
\hline & SITCOM & 71 & 19.2 & 19.2 & 90.8 \\
\hline & OTHER & 34 & 9.2 & 9.2 & 100.0 \\
\hline & Total & 370 & 100.0 & 100.0 & \\
\hline
\end{tabular}

Table 2.2

\begin{tabular}{|c|c|c|c|c|c|}
\hline \multicolumn{2}{|c|}{$\begin{array}{l}\text { CONTAINS PRODUCT } \\
\text { PLACEMENT }\end{array}$} & Frequency & Percent & Valid Percent & $\begin{array}{l}\text { Cumulative } \\
\text { Percent }\end{array}$ \\
\hline \multirow[t]{4}{*}{ Valid } & YES & 231 & 62.4 & 62.4 & 62.4 \\
\hline & NO & 85 & 23.0 & 23.0 & 85.4 \\
\hline & NOT APPLICABLE & 54 & 14.6 & 14.6 & 100.0 \\
\hline & Total & 370 & 100.0 & 100.0 & \\
\hline
\end{tabular}

Table 2.3

\begin{tabular}{|c|c|c|c|c|c|}
\hline \multicolumn{2}{|c|}{$\begin{array}{l}\text { EDUCATIONAL/NEWS } \\
\text { RELATED }\end{array}$} & Frequency & Percent & Valid Percent & $\begin{array}{l}\text { Cumulative } \\
\text { Percent }\end{array}$ \\
\hline \multirow[t]{4}{*}{ Valid } & YES & 102 & 27.6 & 27.6 & 27.6 \\
\hline & $\mathrm{NO}$ & 205 & 55.4 & 55.4 & 83.0 \\
\hline & NOT APPLICABLE & 63 & 17.0 & 17.0 & 100.0 \\
\hline & Total & 370 & 100.0 & 100.0 & \\
\hline
\end{tabular}

Although the majority of subjects believe product placement should not be included in news or educational programming, most, however, believe that this form of advertising adds a sense of realism to television shows (see Table 2.4); does not take away from an artist's integrity (see Table 2.5); and overall, is not a distracting method (see Table 2.6).

Table 2.4 


\begin{tabular}{|c|c|c|c|c|c|}
\hline & REALISM & Frequency & Percent & Valid Percent & $\begin{array}{l}\text { Cumulative } \\
\text { Percent }\end{array}$ \\
\hline \multirow[t]{4}{*}{ Valid } & YES & 234 & 63.2 & 63.2 & 63.2 \\
\hline & NO & 115 & 31.1 & 31.1 & 94.3 \\
\hline & NOT APPLICABLE & 21 & 5.7 & 5.7 & 100.0 \\
\hline & Total & 370 & 100.0 & 100.0 & \\
\hline
\end{tabular}

Table 2.5

\begin{tabular}{|c|c|c|c|c|c|}
\hline \multicolumn{2}{|c|}{$\begin{array}{l}\text { RESTRICTS ARTISTIC } \\
\text { INTEGRITY }\end{array}$} & Frequency & Percent & Valid Percent & $\begin{array}{c}\text { Cumulative } \\
\text { Percent }\end{array}$ \\
\hline \multirow[t]{4}{*}{ Valid } & YES & 107 & 28.9 & 28.9 & 28.9 \\
\hline & NO & 221 & 59.7 & 59.7 & 88.6 \\
\hline & NOT APPLICABLE & 42 & 11.4 & 11.4 & 100.0 \\
\hline & Total & 370 & 100.0 & 100.0 & \\
\hline
\end{tabular}

Table 2.6

\begin{tabular}{|c|c|c|c|c|c|}
\hline & DISTRACTING & Frequency & Percent & Valid Percent & $\begin{array}{c}\text { Cumulative } \\
\text { Percent }\end{array}$ \\
\hline \multirow[t]{4}{*}{ Valid } & YES & 105 & 28.4 & 28.4 & 28.4 \\
\hline & NO & 245 & 66.2 & 66.2 & 94.6 \\
\hline & NOT APPLICABLE & 20 & 5.4 & 5.4 & 100.0 \\
\hline & Total & 370 & 100.0 & 100.0 & \\
\hline
\end{tabular}

The first hypothesis (H1) predicted that those viewers who watch the largest amounts of television will be more aware of product placement than any other group. This hypothesis was accepted. By looking at the results of the cross-tabulation, it appears as if those participants who watch 6-10 hours of television each week are the most aware of product placement (see Table 3.1) However, this group had the largest amount of respondents and, therefore, the percentage of "very aware” is the largest as well (see Table 3.2).

Table 3.1

\begin{tabular}{|c|c|c|c|c|c|c|}
\hline \multirow{2}{*}{$\begin{array}{c}\text { AMOUNT OF TV PER } \\
\text { WEEK }\end{array}$} & \multicolumn{5}{|c|}{ AWARENESS OF PLACEMENT } & \multirow{2}{*}{ Total } \\
\cline { 2 - 5 } & VERY & SOMEWHAT & UNDECIDED & NOT MUCH & NOT AT ALL & NOT \\
\hline
\end{tabular}




\begin{tabular}{|rl|r|r|r|r|r|r|}
\hline Valid & $0-5$ & 19 & 46 & 11 & 16 & 12 & 104 \\
& $6-10$ & 34 & 60 & 5 & 15 & 6 & 120 \\
& $11-15$ & 19 & 33 & 5 & 9 & 6 & 72 \\
& $16-20$ & 13 & 14 & 1 & 5 & 5 & 38 \\
& 20 OR & 17 & 12 & 1 & 4 & 2 & 36 \\
& MORE & 102 & 165 & 23 & 49 & 31 & 370 \\
\hline
\end{tabular}

By dividing the total number of responses in each category by the amount of "very aware" in each column, it becomes clear that, in fact, the group that watches 20 or more hours of television per week is the most aware of product placement (see Table 3.3). Along with this, the group the watches the smallest amount of television per week is the least likely to be aware of product placement.

Table 3.2

\begin{tabular}{|c|c|c|c|c|c|}
\hline \multicolumn{2}{|c|}{$\begin{array}{l}\text { AMOUNT OF TV PER } \\
\text { WEEK }\end{array}$} & Frequency & Percent & Valid Percent & $\begin{array}{l}\text { Cumulative } \\
\text { Percent }\end{array}$ \\
\hline \multirow[t]{6}{*}{ Valid } & $0-5$ & 104 & 28.1 & 28.1 & 28.1 \\
\hline & $6-10$ & 120 & 32.4 & 32.4 & 60.5 \\
\hline & $11-15$ & 72 & 19.5 & 19.5 & 80.0 \\
\hline & $16-20$ & 38 & 10.3 & 10.3 & 90.3 \\
\hline & 20 OR MORE & 36 & 9.7 & 9.7 & 100.0 \\
\hline & Total & 370 & 100.0 & 100.0 & \\
\hline
\end{tabular}

Table 3.3

\begin{tabular}{|c|c|c|c|c|c|}
\hline \multicolumn{2}{|c|}{$\begin{array}{l}\text { AMOUNT OF TV PER } \\
\text { WEEKIAWARENESS } \\
\text { *Cross-Tabulation }\end{array}$} & \multirow{2}{*}{$\frac{\text { Frequency }}{19}$} & \multirow{2}{*}{$\frac{\text { Percent }}{18.2}$} & \multirow{2}{*}{$\frac{\text { Valid Percent }}{18.2}$} & \multirow{2}{*}{$\begin{array}{r}\begin{array}{l}\text { Cumulative } \\
\text { Percent }\end{array} \\
18.2\end{array}$} \\
\hline Valid & $0-5$ & & & & \\
\hline & $6-10$ & 34 & 28.3 & 28.3 & 46.5 \\
\hline & $11-15$ & 19 & 26.3 & 26.3 & 72.8 \\
\hline & $16-20$ & 13 & 34.2 & 34.2 & 107.0 \\
\hline & 20 OR MORE & 17 & 47.2 & 47.2 & 154.20 \\
\hline & Total & 370 & 100.0 & 100.0 & \\
\hline
\end{tabular}

The second hypothesis (H2) predicted that product placement would be recognized in the form of consumables more so than any other form of placement. This hypothesis was also accepted. More than half 53.2\% of the respondents conveyed that 
they have been exposed to product placement in the form of consumables such as food and/or beverage more than any other category (see Table 4.1)

Table 4.1

\begin{tabular}{|c|c|c|c|c|c|}
\hline & & Frequency & Percent & Valid Percent & $\begin{array}{c}\text { Cumulative } \\
\text { Percent }\end{array}$ \\
\hline \multirow[t]{6}{*}{ Valid } & CONSUMABLES & 197 & 53.2 & 53.2 & 53.2 \\
\hline & CLOTHING & 91 & 24.6 & 24.6 & 77.8 \\
\hline & COMPANY & 70 & 18.9 & 18.9 & 96.8 \\
\hline & CLEANING PRODUCT & 4 & 1.1 & 1.1 & 97.8 \\
\hline & OTHER & 8 & 2.2 & 2.2 & 100.0 \\
\hline & Total & 370 & 100.0 & 100.0 & \\
\hline
\end{tabular}

The third hypothesis (H3) predicted that product placement in both television shows and movies would be recognized by the viewers as well-known products. This hypothesis was also accepted. The hypothesis was accepted as a majority but not by an overwhelming amount. Only 34.9\% of viewers "strongly agreed" that products used in television are well-known and 36.2\% “strongly agreed” products used in movies are wellknown (see Tables 5.1, 5.2).

Table 5.1

\begin{tabular}{|c|c|c|c|c|c|}
\hline \multicolumn{2}{|c|}{$\begin{array}{l}\text { WELL-KNOWN TELEVISION } \\
\text { PRODUCTS }\end{array}$} & Frequency & Percent & Valid Percent & $\begin{array}{c}\text { Cumulative } \\
\text { Percent }\end{array}$ \\
\hline \multirow[t]{6}{*}{ Valid } & STRONGLY AGREE & 129 & 34.9 & 34.9 & 34.9 \\
\hline & AGREE & 119 & 32.2 & 32.2 & 67.0 \\
\hline & UNDECIDED & 75 & 20.3 & 20.3 & 87.3 \\
\hline & DISAGREE & 29 & 7.8 & 7.8 & 95.1 \\
\hline & STRONGLY DISAGREE & 18 & 4.9 & 4.9 & 100.0 \\
\hline & Total & 370 & 100.0 & 100.0 & \\
\hline
\end{tabular}

Table 5.2

\begin{tabular}{|l|r|r|r|r|}
\hline WELL-KNOWN FILM PRODUCTS & Frequency & Percent & Valid Percent & $\begin{array}{c}\text { Cumulative } \\
\text { Percent }\end{array}$ \\
\hline Valid STRONGLY AGREE & 134 & 36.2 & 36.2 & 36.2
\end{tabular}




\begin{tabular}{|l|r|r|r|r|} 
AGREE & 107 & 28.9 & 28.9 & 65.1 \\
UNDECIDED & 75 & 20.3 & 20.3 & 85.4 \\
DISAGREE & 32 & 8.6 & 8.6 & 94.1 \\
STRONGLY DISAGREE & 22 & 5.9 & 5.9 & 100.0 \\
Total & 370 & 100.0 & 100.0 & \\
\hline
\end{tabular}

The fourth hypothesis predicted that product placement would be regarded as an ethical practice. Although this hypothesis was accepted (see Table 6.1), it can be seen that even though most respondents feel product placement is an ethical practice, the majority also deem it as deceptive (see Table 6.2). This can be correlated with the fact that whenever subjects were asked whether instances of product placement have every occurred in an unfamiliar setting, the majority responded “yes” (see Table 6.3). And, when asked if they are always aware when it occurs, most responded "no" (see Table 6.1).

Table 6.1

\begin{tabular}{|c|c|c|c|c|}
\hline ETHICAL PRACTICE & Frequency & Percent & Valid Percent & $\begin{array}{c}\text { Cumulative } \\
\text { Percent }\end{array}$ \\
\hline Valid $\quad$ YES & 204 & 55.1 & 55.1 & 55.1 \\
\hline NO & 105 & 28.4 & 28.4 & 83.5 \\
\hline NOT APPLICABLE & 61 & 16.5 & 16.5 & 100.0 \\
\hline Total & 370 & 100.0 & 100.0 & \\
\hline
\end{tabular}

Table 6.2

\begin{tabular}{|c|c|c|c|c|c|}
\hline \multicolumn{2}{|c|}{ DECEPTIVE PRACTICE } & Frequency & Percent & Valid Percent & $\begin{array}{c}\text { Cumulative } \\
\text { Percent }\end{array}$ \\
\hline \multirow[t]{4}{*}{ Valid } & YES & 276 & 74.6 & 74.6 & 74.6 \\
\hline & NO & 63 & 17.0 & 17.0 & 91.6 \\
\hline & NOT APPLICABLE & 31 & 8.4 & 8.4 & 100.0 \\
\hline & Total & 370 & 100.0 & 100.0 & \\
\hline
\end{tabular}

Table 6.3

SURPRISED BY ENCOUNTER/DECEPTIVE PRACTICE *Cross-Tabulation

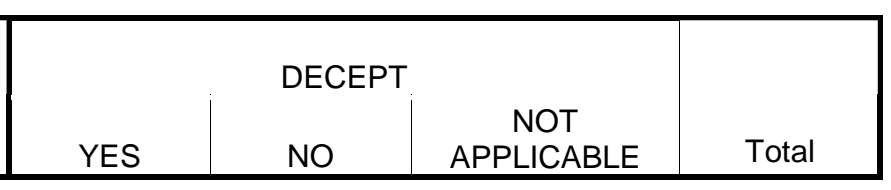




\begin{tabular}{|ll|r|r|r|r|}
\hline SURPRISE & YES & 185 & 37 & 15 & 237 \\
& NO & 51 & 13 & 3 & 67 \\
& NOT APPLICABLE & 40 & 13 & 13 & 66 \\
& Total & 276 & 63 & 31 & 370 \\
\hline
\end{tabular}

Table 6.4

\begin{tabular}{|c|c|c|c|c|c|}
\hline \multirow{2}{*}{\multicolumn{2}{|c|}{$\begin{array}{l}\text { AWARE OF OCCURANCEI } \\
\text { DECEPTIVE PRACTICE } \\
\text { *Cross-Tabulation }\end{array}$}} & \multicolumn{3}{|c|}{ DECEPT } & \multirow[b]{2}{*}{ Total } \\
\hline & & YES & $\mathrm{NO}$ & $\begin{array}{c}\text { NOT } \\
\text { APPLICABLE }\end{array}$ & \\
\hline \multirow[t]{4}{*}{ OCCUR } & YES & 62 & 18 & 7 & 87 \\
\hline & NO & 211 & 45 & 15 & 271 \\
\hline & APPLICABLE & 3 & 0 & 9 & 12 \\
\hline & Total & 276 & 63 & 31 & 370 \\
\hline
\end{tabular}

\section{Discussion}

There were various limitations throughout this study. First, the sample size was extremely homogeneous. The cluster sample was taken strictly from students at West Virginia University. If the researcher would have included the general public in the overall sample, the sample would have been more heterogeneous. Also, the students surveyed consisted mainly of 18-to-20 year olds. If the researcher would have expanded to different parts of the university, the sample may have been more diverse in age range.

The researcher could have used a stratified random sample, which often gives a greater precision for outcomes. In doing stratified random samplings, the researcher could have taken the population and divided it into sub-categories. For the purpose of this study, the researcher obtained a sample of 370. If a larger sample were used such as 500 respondents, the margin of error would have slightly decreased.

The researcher could have conducted the study in a manner other than handing out written surveys. For instance, she could have prepared an experiment in which the participants viewed samples of product placement in both prime-time television and film 
and recorded attitudes based on their experience. This would eliminate the bias of those who watch little television and those who are unaware of the concept.

The researcher could have also administered an in-depth interview in which respondents were asked about their attitudes towards product placement. With the use of this type of interview, the researcher would have had the ability to ask follow-up questions that pertained to the survey. This would also create an increase in validity and reliability because the research would have been observed on a more personal basis.

\section{Conclusion}

This research was conducted to explore public awareness of product placement as well as any ethical considerations that coincide with the practice. The researcher concludes that while the sample studied is aware of product placement and believes it to be an ethical practice, they, at the same time believe it can be deceptive and/or misleading and are often surprised by instances of the form of advertising. The researcher found it very interesting that an overwhelming majority of those surveyed $74.6 \%$ believe that the practice is deceptive. The researcher believes that this may be due to the idea that the sample admitted to often being surprised by the practice.

For future study in this area, researchers may want to focus on a larger and more heterogeneous sample for analysis. Along with this, future researchers may also want to focus on other aspects to study, such as effects of product placement on total recall and buyer behavior based on product placement. It would be quite interesting to see if viewers in a sample were more prone to purchasing an item based on the frequency in which they viewed it. 


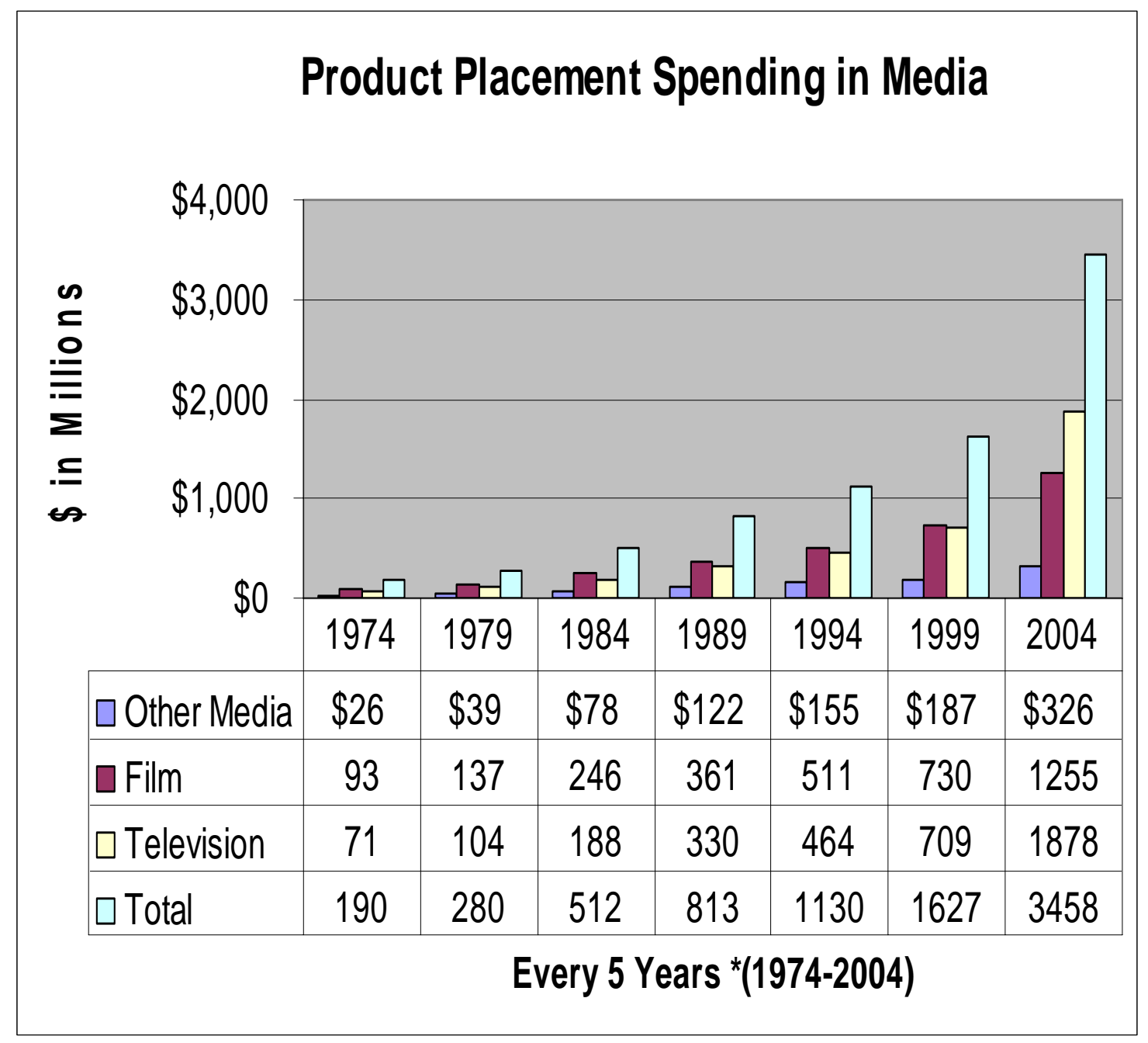

(Figure 1-PQ Media Research) 


\section{Shares of Product Placement Spending 2004}

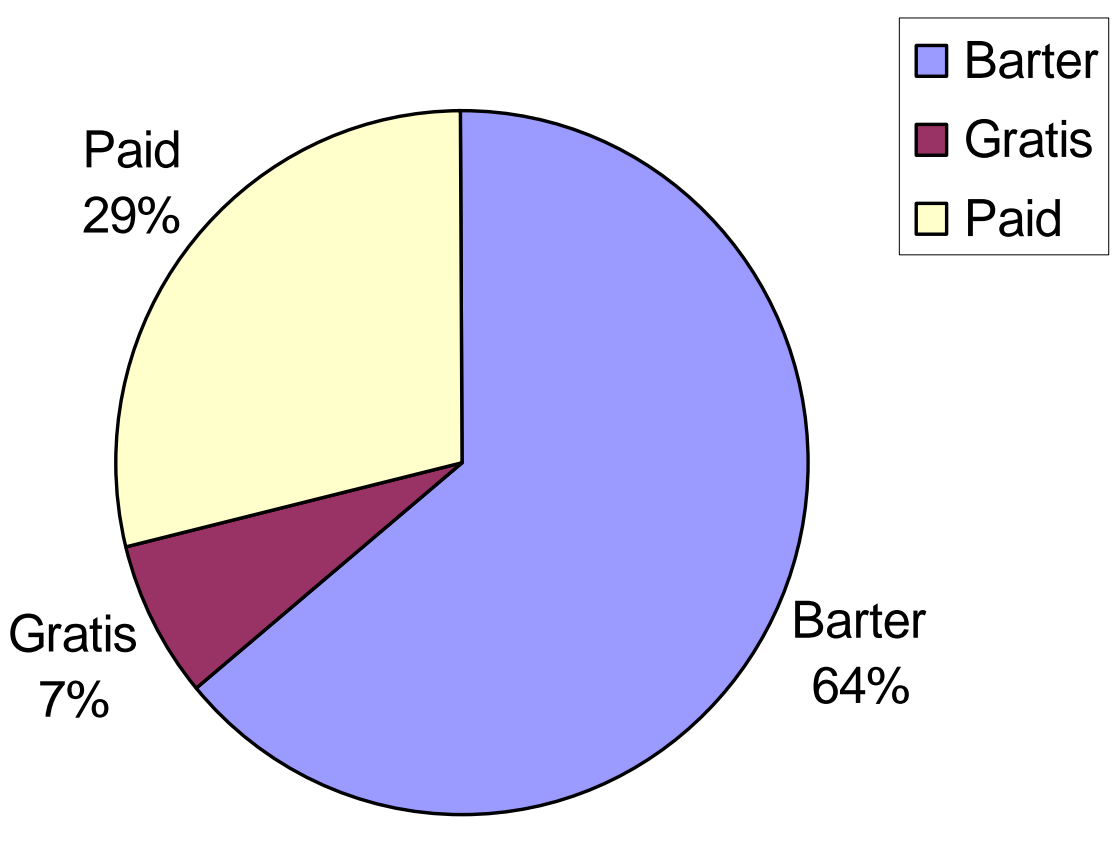

(Figure 2-PQ Media Research) 


\section{Projected Product Placement Spending in Media}

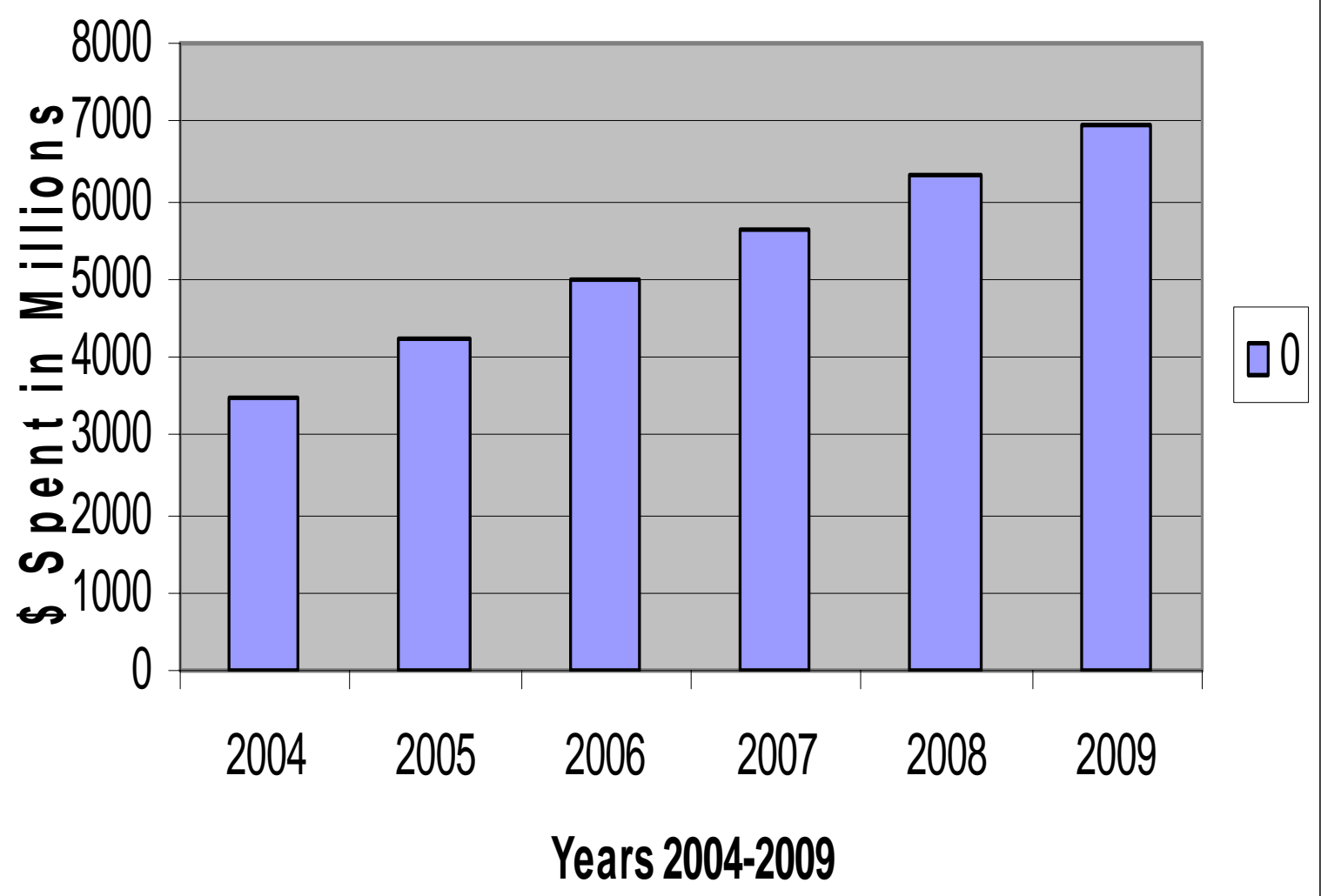

(Figure 3-PQ Media Spending) 


\section{Selected Bibliography}

Andersen, Kenneth E., Persuasion Theory and Practice. Boston, MA: Allyn and Bacon, Inc., 1971.

Atkinson, Claire and Jon Fine, “Nielson Plumbs Product Placement,” Advertising Age, 75, 37 (2004).

Balasurbramanian, Stanley, "Beyond Advertising and Publicity: Hybrid Messages and Public Policy Issues,” Journal of Advertising 23, 4 (March 1994): 42.

Bergh, B. Vanden and Katz, Helen, Advertising Principles. Choice, challenge, change. Lincolnwood, IL: NTC Business Books, 1998.

Friedman, Wayne, “Bonanza Remains Elusive,” Television Week, 11 Oct. 2004: 22.

Goodale, Gloria “Ads You Can’t Subtract,” Christian Science Monitor, 93, 62 (2001).

Harrison, Edward, “Cashing in: E.T. Led the Way,” Los Angeles Times 20 Aug. 1999:25.

Karr, James, “Brand Placement: A Review,” Journal of Current Issues and Ethics, 13, 4, (1998).

Magiera, Michael, “Products in Movies: How big a deal,” Advertising Age, 55, 4 (1991).

McCarthy, Matthew, “Of all the Jim Beam joints,” Chicago Tribune, 18, Aug. 1996: E17.

McCarthy, Paul, “Ad ventures in tinsel town,” Sydney Morning Herald, 5, Jan. 1998: 8.

Mishra, R., “TV Spot Gaffe Revives Decade Old Suspicion,” The Boston Globe 13 Sept. 2000: A4.

Ostrow, Joanne, “When Ads are the Stars,” The Denver Post, 28 Nov. 2004: F1.

Packard, Vance, The Hidden Persuaders, New York City, NY: David McKay Company, 1974.

Park, Hyunsoo and Weigold, Michael F. “Advertising Ethics,” Journal of Mass Media Ethics, (May 1999).

Patton, Michael Q., Qualitative and Evaluation Research Methods. London: Sage Publications, 2000.

Phillips, Michael J. Ethics and Manipulation in Advertising. CT: Quorum Books, 1997. 
Reardon, Kathleen Kelley, Persuasion: Theory and Context. CA: Sage Publications, 1981.

Richards, Jeff, Deceptive Advertising: Behavioral Study of a Legal Concept. Hillsdale, NJ: L. Erlbaum Associates, 1994.

Rothenburg, Robert "Marketing's borders blurred by product placement revival," Advertsing Age 16, no. 1 (2001).

Rushkoff, Douglas, Coercion: Why We Listen to What "They" Say, NY: Riverhead Books, 1999.

Russell, J.T., and Lane, R., Kleppner's Advertising Procedures. NJ: Prentice Hall, 2002.

Reardon, Kathleen Kelley, Persuasion: Theory and Context. CA: Sage Publications, 1981.

Shiner, Roger A., Freedom of Commercial Expression. NY: Oxford Press, 2003.

Sheehan, Kim, Controversies in Contemporary Advertising. CA: Sage Publications, 2003.

Storey, Michael, "Place ad: The line between TV series and infomercial has been crossed,” Arkansas Democrat Gazette, 13 Jan. 2006: D3.

Vanden Bergh, B. and Helen Katz, Advertising Principles. Choice, challenge, change,Lincolnwood, IL: NTC Business Books, 1998.

Weis, Lois, "Products wining movie auditions," Advertising Age, 56, 2 (1985). 


\section{APPENDIX A}

\section{SAMPLE OF STUDIO CONTRACT}

1. You represent and warrant that the Goods are merchantable and suitable for their intended use. You shall indemnify, defend and hold harmless the Studio, its parent, affiliated and subsidiary companies, and its officers, directors, age nts and employees from and against any claims, actions, damages and costs (including any reasonable attorneys' fees in connection therewith) arising from any defect in any Goods supplied by you and/or any breach of any representation and/or warranty made by you. The Studio shall give you prompt written notice of any claim of which the Studio is advised so as to give you the opportunity to assume the defense thereof. Failure to give notice does not constitute a breach of this Agreement. Notice shall be sent by certified mail to the following address:

Settlement by the Studio without your prior written consent shall release you from the indemnity as to the claim or action so settled.

2. You hereby authorize the use of the name and likeness and designs, trademarks, logos and physical characteristics of, the Goods, in the Picture.

3. You are aware that the existence and contents of this Agreement may be revealed to third parties, including without limitation, network executives and government agency officials, and you so consent.

4. The Studio reserves the right to have, but will not intentionally feature, competitive product(s) in the Picture.

5. This Agreement shall be interpreted under the laws of the State of California.

6. Nothing contained herein shall in any way constitute a partnership or joint venture between the parties hereto or be construed to evidence the intention of the parties to constitute such. Neither of the parties hereto shall hold itsel f out contrary to the terms of this provision by advertising or otherwise.

7. If any provision of this Agreement is adjudged void, voidable or illegal, such adjudication shall not affect the remaining provisions hereof.

8. No waiver of any breach of any provision of this Agreement shall be deemed a continuing waiver thereof or a waiver of the breach of any other provision hereof.

9. This Agreement, when signed by the parties, shall constitute the entire understanding of the parties with respect to the subject matter, superseding all prior and/or concurrent representations, promises, understandings, and agreements, oral or in writing, between them with respect thereto; it may not be amended or rescinded except by a writing signed by the parties. 


\section{THIS AGREEMENT IS VALID ONLY WHEN SIGNED BY A DULY}

\section{AUTHORIZED REPRESENTATIVE OF THE STUDIO.}

ACCEPTED AND AGREED TO:

THE STUDIO

BY:

BY:

ITS: ITS:

(Figure 3) 


\section{APPENDIX B}

Dear Respondent,

I am requesting your participation in a research project to study product placement in prime-time television shows. This project is a research study being conducted in partial fulfillment of the requirements for a master's thesis. Along with this letter is a short questionnaire that asks a variety of questions about product placement practices. I am asking you to look over the questionnaire and, if you choose to do so, complete it and hand it in to me.

The purpose of this study is to create a basic understanding of the awareness of product placement and how one feels about its ethical considerations. I hope, with your help, the results of this survey will be useful in determining this information.

Your participation in this study is voluntary and you have the right not to answer any question if you feel uncomfortable at any time. If you choose not to participate or to withdraw from the study at any point, there will be no penalty on your class standing or grades.

I do not know of any risks to you if you decide to participate in this survey and I guarantee that your responses will not be identified with you personally. All responses will be kept anonymous. You should not print your name on the questionnaire, but rather identify yourself by including the last three digits of your student identification number.

The survey should take about 10 minutes to complete. I hope you will take the time to complete this questionnaire and return it. If you have any questions or concerns about completing the survey or about being in this study, you may contact Leigh Ann Hornick, project evaluator at (304) 293-3505 ext. 5424 and/or Professor Dana Coester, committee chair at (304) 293-3505 ext. 5411.

Sincerely,

Leigh Ann Hornick

Graduate Student 


\section{Questionnaire}

\section{LAST THREE DIGITS OF STUDENT IDENTIFICATION NUMBER:}

Definition: Product placement is the appearance of a product or service in a broadcast program or movie, paid for by the manufacturer to gain exposure for the product or service.

Please answer the following questions to the best of your ability.

1) Are you a male or female?
o Male
o Female

2) What is your age?
o $18-20$
o $21-23$
o $24-26$
o Other

3) Generally, when watching television I am...
o Alone
o With friends/family
o Other

4) How often would you say you watch television per week?
o 0 -5 hours
o 6-10 hours
o 11-15 hours
o 16-20 hours
o $20+$ hours

5) Were you aware of the existence of product placement before reading the introduction to this questionnaire?
o Very
o Somewhat
o N/A
o Not much
o Not at all

6) What type of television do you watch most often? (Please choose one).

o News-local/national

o Sports related

o Reality Based

o Dramas

o Sitcoms

o Other 
7) Using your answer from question 6, does this type of programming usually contain product placement?
o Yes
o No
o N/A

8) How often would you say you watch prime-time television a week? (This includes any show on a national network-ABC, CBS, NBC from 7-11 p.m., Monday-Friday).
o 0 -5 hours
o 6-10 hours
o 11-15 hours
o 16-20 hours
o $20+$ hours

9) Overall, would you say your encounters with product placement have been...
o Very positive
o Somewhat positive
o Undecided
o Somewhat negative
o Very negative

10) Have instances of product placement ever occurred in a setting where didn't expect it?
o Yes
o No
o N/A

11) Have you watched at least one show on a major network during prime-time in its entirety this week?
o Yes
o No
o N/A

12) What types of product placement are you most familiar with? (Please choose one). Those in the form of...

o Consumables — food and/or beverage

o Clothing including footwear

o Company/Corporation including logo

o Cleaning Product

o Other 
13) When thinking about product placement, what first comes to mind?

o A product/brand being used

o A product/brand being verbally referred to

- A product/brand being seen in clear view

o A product/brand barely seen in the background

o Other

14) Do you believe that product placement belongs in educational and/or news programming?
o Yes
o No
$0 \quad$ N/A

15) Do you believe as a viewer you are always aware when product placement occurs?
o Yes
o No
o N/A

16) Do you believe product placement adds a sense of realism to a television show?
o Yes
o No
o N/A

17) Do you believe product placement takes away from a television show?
o Yes
O No
o N/A

18) Do you feel product placement compromises an artist's work?
o Yes
o No
o N/A

19) Do you find yourself easily distracted when there is a product in the background of a television show and you are unable to make out the specific brand?
o Yes
o No
o N/A

20) Do you feel product placement is an essential part of today's television shows?
o Yes
o No
$0 \quad$ N/A 
21) Do you feel product placement is an ethical practice?
o Yes
o No
o N/A

22) Do you feel product placement should have certain rules and regulations to accompany it?
o Yes
o No
O N/A

23) Do you feel product placement can be deceptive at times?

o Yes

o No

o N/A

Please answer the below paired attitudinal questions to the best of your ability using the following scale: 1 =Strongly Agree; $5=$ Strongly Disagree...

24) From the product placements I have been exposed to on television, brands were shown in a positive light.
$0 \quad 1$
$0 \quad 2$
03
$0 \quad 4$
o 5

From the product placements I have been exposed to in the movies, brands were shown in a positive manner.
o 1
02
03
04
05

25) Product placement is an unethical form of advertising in television shows.
o 1
$0 \quad 2$
03
04
O 5

Product placement is an unethical form of advertising in movies.
o 1
$0 \quad 2$
o 3
O 4
○ 5 
26) Brands that appear in television product placement are usually well-known brands.
0 1
02
03
04
05

Brands that appear in movies are usually well-known brands.
o 1
02
03
04
05

Thank you for completing this survey. If you would like further information pertaining to the outcome of this study, please contact Leigh Ann Hornick at (304) 293-3505 ext. 5424. 


\begin{abstract}
APPENDIX C
Entertainment Marketing Association (EMA): Mission Statement and Code of Standards and Ethics (from Organizational Website www.erma.org)
\end{abstract}

\title{
CODE OF STANDARDS AND ETHICS
}

1. A member shall exemplify high standards of honesty and integrity while carrying out obligations to a client or employer.

2. A member shall deal fairly with past or present clients or employers and with fellow practitioners, giving due respect to the ideal of free inquiry and the opinion of others.

3. A member shall adhere to the highest standards of accuracy an truth, avoiding extravagant claims, unfair comparisons, or taking credit for ideas and projects borrowed from others.

4. A member shall not knowingly disseminate false or misleading information and shall act promptly to correct erroneous communications for which he or she is responsible.

5. A member shall not guarantee the achievement of specified results beyond the member's control.

6. A member shall not represent conflicting or competing interests without the express consent of those concerned given after full disclosure of the facts.

7. A member shall not accept fees, commissions, gifts, or any other consideration from anyone except clients or employers for whom services are performed, without their express consent, given after full disclosure of the facts.

8. A member shall scrupulously safeguard the confidences and privacy rights of present, former, and prospective clients or employers.

9. a member shall not intentionally, or knowingly, damage the professional reputation or practice of another employer.

10. If a member has evidence that another member has been guilty of unethical, illegal, or unfair practices, including those in violation of this code, the member is obligated to present the information promptly to the proper authorities within the Association, for investigation and possible action.

11. A member called as a witness in a processing for enforcement of this code is obligated to appear, unless excused for sufficient reason by the authorities of this Association.

12. A member shall, as soon as possible, server relations with any organizations or individuals if such relationship requires conduct contrary to the articles of this code. 